\title{
Heat transfer and air movement behaviour in a double-skin façade
}

\author{
J. Darkwa, Y. Li, DHC. Chow \\ Centre for Sustainable Energy Technologies (CSET) \\ The University of Nottingham Ningbo China \\ 199 Taikang East Road \\ Ningbo 315100 , P. R. China \\ Tel: +86 574 88180255; Fax: +8657488180313 \\ Email: jo.darkwa@ nottingham.edu.cn
}

\begin{abstract}
Theoretical and practical evaluation of a naturally-ventilated double skin façade has been undertaken. The study has shown that the double skin façade (DSF) system is capable of supplying adequate ventilation to various levels with little or no additional heating during winter thus saving the bulk percentage of the heating load on the building. However there was an element of overheating in the DSF which may have contributed to an additional cooling load on the building. Even though the operational strategy of mixing return air with trapped air in the cavity helped to minimise the overheating effect, there was still some considerable level of temperature increase in the DSF. Effective thermal management control strategies and systems are therefore encouraged in the design and operation of DSFs.
\end{abstract}

Keywords: Heat transfer; Natural ventilation; Double Skin Façade; Overheating 


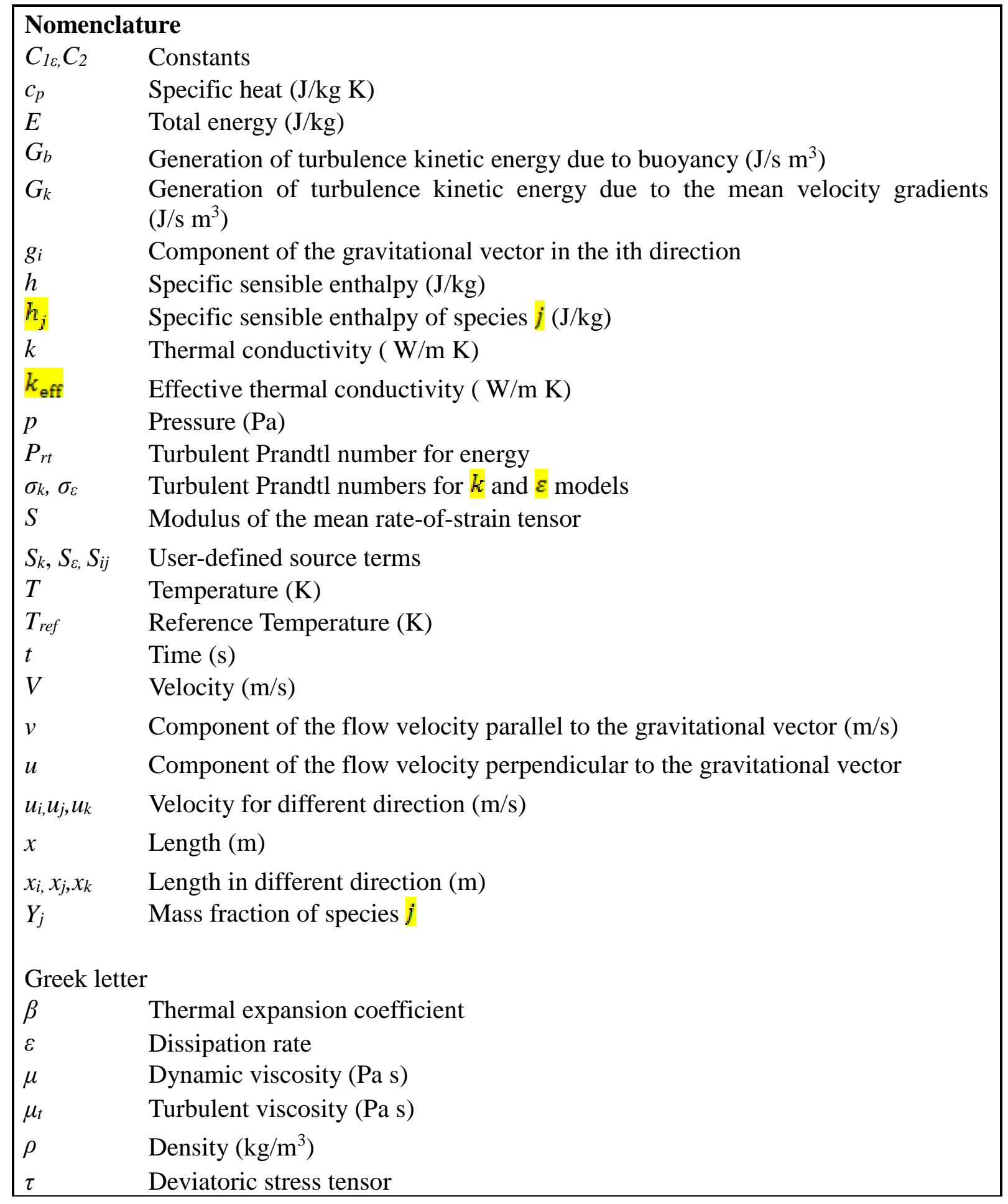




\subsection{Introduction}

Within the framework of modern building design concepts, double skin façades (DSFs) have emerged as one of the potential energy saving design features being promoted around the world. For instance recent rapid economic development in China has seen a rising number of new commercial buildings with DSFs especially in the hot-summer and coldwinter regions such as Shanghai and Hangzhou [1]. DSF systems normally consist of internal walls and additional external walls with air cavity between the inner and outer skins. As compared with conventional facade systems, DSFs are credited with providing significant reduction in energy consumption, providing for natural ventilation even in skyscrapers, controlling valuable noise reduction from outside and helping to adjust indoor climates in both new and some existing buildings [2-4]. DSFs have also the benefit of creating a visually transparent architecture that is impossible with conventional curtain wall facades with similar properties.

Even though these studies support the energy efficiency potential of DSFs, there is an issue relating to overheating during warm periods which tend to create additional cooling load in buildings through solar heat gains on the façades especially at higher floor levels [5-9]. In some DSF cases shading devices such as mid-pane blinds and internal blinds are being used in providing solar shading but they are believed to contribute to additional heat source linked with complex long wave radiation exchange, increased air temperature and buoyancy effect in the cavities [10]. These interrelated parameters are all part of the difficulties facing thermal management of DSFs. Other dynamic factors such as air flow rate, variable convective surface film and radiation heat transfer coefficients and transmission of solar radiation also make modelling and simulation of DSFs difficult. 
Meanwhile a number of studies [11-14] have been undertaken and reported about flow visualization and thermal performance of DSFs but there is still inadequate research information about their true effectiveness during cold, hot and humid seasons. In order to gain more understanding and to acquire reliable data for future design and simulation exercises, the current study evaluates the airflow and thermal performance behaviour of a DSF building located in a hot and cold region.

\subsection{The DSF Building}

The building under evaluation is located at Ningbo China which has a subtropical climate, featuring mild temperatures, moderate to high humidity and distinct seasons. The hottest month is normally July, where temperatures could reach about $39{ }^{\circ} \mathrm{C}$ whereas the coldest month is January, with temperature around about $-5{ }^{\circ} \mathrm{C}$ at night. The building incorporates a double skin façade south facing wall which tilts forward from both the top and the base of the wall. The tilted surface helps to deflect most of the solar radiation and thus reduce solar transmission through the façade during summer period. During winter period the opening at the top of the DSF is closed to allow fresh air to enter the building through openings in the base of the inner glass façade. The return air supply is evacuated through the top opening in the light-well as shown in Fig. 1a. In summer, the DSF serves as a thermal buffer for reducing heat gain into the building and for removing the extract ventilation from the building as shown in Fig. $1 b$. 


\subsection{Mathematical modelling}

FLUENT software [15] was used to simulate the airflow and temperature distribution in the cavity of the DSF. Normally this requires the geometric space to be divided into a finite volume grid. By default grid regions are spaced uniformly using a system that is calculated to be as close as possible to the user-defined default grid spacing. However, very narrow regions resulting in long, narrow grid cells or cells having a high aspect ratio need to be avoided since they tend to result in unstable solutions that can fail to converge. Large numbers of key coordinates can also lead to overly complex grids and correspondingly high calculation run times and excessive memory usage. Therefore for the benefit of saving computational resources and calculation time as well as minimizing errors, an initial grid size of $0.5 \mathrm{~mm}$ was varied in steps to a maximum size of $2 \mathrm{~mm}$ (i.e. about 1.5 times the initial mesh size) until the solution became independent of the mesh resolution. The mesh volumes were solved to a residual of less than the default criterion of $10^{-3}\left(<10^{-3}\right)$ and that of energy to a residual less than $10^{-6}\left(<10^{-6}\right)$. The model was also simplified to a two dimensional section of the building.

\subsection{Generalized Transport Equations}

The Boussinesq approximation (Eq.1) was used to solve the buoyancy-driven air flows and natural convection. For the turbulence model, the Standard k-epsilon $(k-\varepsilon)$ model [16] was applied since it is one of the most frequently used models in fluid dynamics and also the most common turbulence model for fluid flow simulations. It is also preferred to other models since it is able to deal with laminar and transitional flow patterns at the same time. 
The governing flow equations for the fluid density as a function of temperature, conservation of heat, mass and momentum were expressed as follows:

Flow density:

$$
\left(\rho-\rho_{0}\right) g \approx-\rho_{0} \beta\left(T-T_{0}\right) g
$$

Energy Equation in vector form

$$
\frac{\partial}{\partial t}(\rho E)+\nabla \cdot(\vec{v}(\rho E+p))=\nabla \cdot\left(k_{\text {eff }} \nabla T\right)+S_{h}
$$

Mass conservation equation:

$$
\frac{\partial \rho}{\partial t}+\nabla \cdot(\rho \vec{v})=S_{m}
$$

Momentum conservation equation

$$
\frac{\partial}{\partial x}(\rho \vec{v})+\nabla \cdot(\rho \vec{v} \vec{v})=-\nabla p+\nabla \cdot(\overline{\bar{\tau}})+\rho \vec{g}+\vec{F}
$$

The modelled transport equations for $k$ and $\varepsilon$ are expressed as:

Turbulent kinetic energy (k-equation)

$$
\frac{\partial}{\partial t}(\rho k)+\frac{\partial}{\partial x_{j}}\left(\rho k u_{j}\right)=\frac{\partial}{\partial x_{j}}\left[\left(\mu+\frac{\mu_{t}}{\sigma_{k}}\right) \frac{\partial k}{\partial x_{j}}\right]+G_{k}+G_{b}-\rho \varepsilon+S_{k}
$$

Dissipation ( $\varepsilon$-equation)

$$
\frac{\partial}{\partial t}(\rho \varepsilon)+\frac{\partial}{\partial x_{j}}\left(\rho \varepsilon u_{j}\right)=\frac{\partial}{\partial x_{j}}\left[\left(\mu+\frac{\mu_{t}}{\sigma_{\varepsilon}}\right) \frac{\partial \varepsilon}{\partial x_{j}}\right]+\rho C_{1} S \varepsilon-\rho C_{2} \frac{\epsilon^{2}}{k+\sqrt{v \varepsilon}}+C_{1 \varepsilon} \frac{\varepsilon}{k} C_{3 \varepsilon} G_{b}+S_{s}
$$

The generation of turbulence kinetic energy due to the mean velocity gradient in accordance with Boussinesq hypothesis [17] is given as;

$$
\begin{aligned}
& G_{k}=\mu_{t} S^{2} \\
& G_{b}=\beta g_{i} \frac{\mu_{t}}{P r_{t}} \frac{\partial T}{\partial x_{i}} \\
& \beta=-\frac{1}{\rho}\left(\frac{\partial \rho}{\partial T}\right)_{p}
\end{aligned}
$$


In FLUENT and by default, the generation of turbulence dissipation energy due to buoyancy is neglected. $G_{b}$, is therefore taken as zero in the dissipation $\varepsilon$-equation.

Other terms are given as;

$C_{1}=\max \left[0.43, \frac{\eta}{\eta+5}\right] ; \eta=S \frac{k}{\varepsilon} ; S=\sqrt{2 S_{i j} S_{i j}}$ (modulus of the mean rate-of-strain tensor)

$C_{2}$ and $C_{1 \varepsilon}$ are constants.

$C_{3 \epsilon}=\tanh \left|\frac{v}{u}\right|$

In this flow model, the buoyant shear layers are perpendicular to the gravitational vector and therefore, $C_{3 \varepsilon}=0$.

The model constants are given as;

$C_{1 \varepsilon}=1.44, C_{2}=1.9, \sigma_{k}=1.0, \sigma_{\epsilon}=1.2$

The dissipation modelled energy equation is obtained as [18];

$\frac{\partial}{\partial t}(\rho E)+\frac{\partial}{\partial x_{i}}\left[u_{i}(\rho E+p)\right]=\frac{\partial}{\partial x_{j}}\left(k_{\text {eff }} \frac{\partial T}{\partial x_{j}}+u_{i}\left(\tau_{i j}\right)_{\text {eff }}\right)$

Where $E, k_{\text {eff }}$ and $\left(\tau_{i j}\right)_{\text {eff }}[19]$ are expressed as:

$E=h-\frac{p}{\rho}+\frac{v^{2}}{2}$

$\left(\tau_{i j}\right)_{\text {eff }}=\mu_{\text {eff }}\left(\frac{\partial u_{j}}{\partial x_{i}}+\frac{\partial u_{i}}{\partial x_{j}}\right)-\frac{2}{3} \mu_{\text {eff }} \frac{\partial u_{k}}{\partial x_{k}} \delta_{i j}$

$h=\sum_{j} Y_{j} h_{j}+\frac{p}{\rho}$

$h_{j}=\int_{T_{\text {ref }}}^{T} c_{p, j} d T$

$k_{\text {eff }}=k+\frac{c_{p} \mu_{t}}{P r_{t}}$ 


\subsection{Boundary conditions and assumptions}

The air flow and the temperature response were modelled for a steady state condition. In this regard, the flow model for the winter season was calculated based exclusively on buoyancy generated by solar radiation. The energy equation was calculated through Discrete Transfer Radiation Model (DTRM). The external air temperature was fixed at $4.9^{\circ} \mathrm{C}$ whereas the main external wind velocity was considered from the south at $0.5 \mathrm{~m} / \mathrm{s}$.

The flow model for summer season was set by assuming the value of solar radiation for the summer solstice at $30{ }^{\circ} \mathrm{N}$ and with an outside mean temperature of $36{ }^{\circ} \mathrm{C}$. It was assumed that a minimum area of $0.1 \mathrm{~m}^{2}$ at the bottom of the inner glass façade and an area of $2 \mathrm{~m}^{2}$ at the top of the glass facing the light-well on levels 1- 4 were opened in winter. In summer a minimum area of $2 \mathrm{~m}^{2}$ at the top of the inner glass façade and an area of $2 \mathrm{~m}^{2}$ at the top of the glass facing the light-well were also opened on levels 1- 4. Tab. 1 shows the general data for the simulation exercise.

\subsection{Theoretical Evaluation}

\subsection{Winter mode}

Fig. 2 illustrates the air flow profile within the DSF and in the light-well on each of floor. The velocity contours show continuous air movement created by the stack effect within the DSF and the effect of the heated air in the buffer area at the top of the light-well. The result indicates that a maximum air flow velocity of up to $0.5 \mathrm{~m} / \mathrm{s}$ is achievable. Fig. 3 shows the contours of static temperature profile within the DSF. There was an increase in temperature difference between the inlet and the outlet of the DSF which was attributed to accumulated heat and buoyancy effects. It demonstrates that the DSF is able to increase the inlet fresh air temperature by up to $15{ }^{\circ} \mathrm{C}$ whilst the overall room temperature could also reach an average temperature of $18{ }^{\circ} \mathrm{C}$ mainly due to the benefit of the internal heat gains. 


\subsection{Summer mode}

In summer the outlet of the DSF is fully opened to enable trapped hot air to be evacuated. Fig. 4 shows how the flow pattern in the room encourages continuous air extraction through the outlet of the DSF with level 4 achieving the highest velocity. The temperature profile in Fig. 5 indicates that the inlet air temperature could be reduced from about $33{ }^{\circ} \mathrm{C}$ to $26^{\circ} \mathrm{C}$ at the outlet of the DSF. This means that the return air from the building is able to minimise the heating effect in the DSF in accordance with the operational strategy. It does however appear that the flow rate at each level has to be re-balanced to avoid excessive temperature stratification in the building.

\subsection{Experimental study}

The factors affecting the performance of the double skin facade are the airflow rates and the temperature distribution in the cavity. For the benefit of validating the theoretical results, meteorological and operational data of the DSF were collected for January (being the coldest month in winter) and for July (being the hottest month in summer).

\subsection{Meteorological data}

An integrated weather station and a solar pyranometer (see Fig. 6) were installed for the measurement of the environmental variables such as temperature, solar radiation and wind speed. Figs. 7 and 8 show the results of the mean daily global solar radiation and ambient temperature profiles from 9am to $5 \mathrm{pm}$ for the monitored days in July 2012 and January 2013 respectively. The maximum solar radiation/ambient temperature values obtained were 1178 W.m-1/ $38{ }^{\circ} \mathrm{C}$ for July and 796 W.m-1/ $13.2{ }^{\circ} \mathrm{C}$ for January. The corresponding wind velocity profiles are presented in Figs. 9 and 10 with July 2012 recording a maximum velocity of $2.3 \mathrm{~m} / \mathrm{s}$ and January 2013 achieving $1.4 \mathrm{~m} / \mathrm{s}$ 


\subsection{Air velocity}

Airflow rate for each floor may be determined by measuring the air velocity and the area of air inlet points. However in natural ventilated DSF systems, measurement of air velocities can be complex and difficult due to the randomness nature and the dynamic flow condition of the air as well as the buoyancy effect in the cavity. Different methods and airflow velocity devices have therefore been used in past investigations by other researchers.

For instance Kalyanova [20] applied the pressure difference, velocity and the tracer gas methods in an airflow measurement and found the latter two methods to be more reliable. Kim et al. [21] also used velocity sensors to determine airflow rates in a double skin façade. In this regard the velocity method (using a hot wire anemometer) was selected for this experimental study in measuring the air velocities at various locations as shown in Fig. 11. Air velocities were for levels 2-4 only. Levels 1 and 5 were not monitored since the mode of supply and extract ventilation methods are different. The inlet air dampers for Level 3 and 4 are in two equal sections whereas Level 2 is in three equal sections. For this test, the air flow measurement was limited to one of each section. The air velocities for summer period were not monitored since fresh air supply was provided by a mechanical ventilation unit and not by the DSF.

\section{$\underline{\text { Winter mode }}$}

Fig. 12 represents the velocity profiles for various levels in the DSF during the monitored days in winter. The highest mean velocity occurred at Level 4 with a maximum velocity of $0.82 \mathrm{~m} / \mathrm{s}$ as against outdoor wind velocity of $4.03 \mathrm{~m} / \mathrm{s}$. This is in agreement with the theoretical prediction which confirmed the buoyancy effect within the DSF where Level 4 recorded the highest velocity reading. Level 2 achieved the lowest and the most stable velocity readings mainly due to the fact that it has the largest cross sectional area in 
comparison with other sections within the DSF. As presented in Tab. 2 and with the exception of Level 2, it can be seen that the DSF is capable of supplying more than adequate fresh air into various areas through only one section of the inlet air dampers when compared with the design values in Tab. 3. This means that all the three dampers would have to be opened at Level 2 in order to meet the design flow rate.

\subsection{Air temperature}

Thermocouples have proved to be popular for the measurement of temperatures in DSFs. This is due to their high level of accuracy, proper measuring range, high linearity and the flexibility that they provide during installation. For instance, Appelfeld and Svendsen [22] applied T-type thermocouples to obtain the temperatures in a ventilated window system. Zollner [23] also measured the air temperature in a double skin façade with a K-type thermocouples under a turbulent mixed convection fluid flow condition. For these reason, an Omega K-type thermocouple (Omega KK-K-30-SLE, percentage error of $0.4 \%$ ) with measuring range from $-200{ }^{\circ} \mathrm{C}$ to $1370{ }^{\circ} \mathrm{C}$ was chosen for the air temperature measurements in the cavity. In total six thermocouples were installed and connected to a dedicated data logger for the measurement of temperatures at different levels in the cavity as shown in Fig. 13.

\section{$\underline{\text { Winter mode }}$}

Fig. 14 shows the temperature profiles for the monitored days in January 2013. As suspected there was a clear evidence of temperature gradient within the DSF with the outlet position displaying the highest temperature profiling. The analysis shows that the DSF is able to increase the fresh air temperature by about $12.2{ }^{\circ} \mathrm{C}$ as summarised in Table 4 . 


\section{$\underline{\text { Summer mode }}$}

Fig. 15 shows the temperature profiles at various levels within the DSF on selected days in July 2012. Even though there was some level of mixing between the return air from the rooms and the air in the cavity (as per the operational strategy), there was considerable evidence of overheating in the DSF which contributes to additional source of cooling load on the building. The results are summarised in Table 5 showing the mean cavity air temperatures for selected days in July 2012 where the highest outlet temperature reached about $41{ }^{\circ} \mathrm{C}$ as

against an ambient temperature of $36^{\circ} \mathrm{C}$. The overheating is further demonstrated in Fig 16 with a thermographic image of the surface of the DSF for a typical day in July 2012 where temperature reached about $51{ }^{\circ} \mathrm{C}$. Such high temperature level could easily increase heat transmission into the indoor areas if there is no effective heat removal mechanism.

\subsection{Discussions and Conclusions}

The study has shown a good level of comparison between the theoretical and the experimental results. For instance the maximum mean theoretical and practical air flow velocities were achieved as $0.5 \mathrm{~m} / \mathrm{s}$ and $0.82 \mathrm{~m} / \mathrm{s}$ respectively during winter operation. Their corresponding fresh air temperatures also increased by $15{ }^{\circ} \mathrm{C}$ and $12.2{ }^{\circ} \mathrm{C}$ respectively. The study has therefore demonstrated that the DSF system is capable of supplying adequate ventilation to various levels with little or no additional heating during winter. This means that the bulk percentage of the heating load on the building can be saved by the DSF ventilation system. It however appears that the motorised fresh air dampers have to be re-adjusted to avoid either over or under supply of fresh air into the rooms.

As already stated, overheating tends to be the main issue affecting the thermal performance of DSF systems in summer as evidenced in Figs 15 and 16. Even though the operational strategy of mixing return air with trapped air in the cavity helped to minimise the 
overheating effect, there was still some considerable level of temperature increase in the DSF as indicated in Tab. 5. The specific findings may therefore be summarised as follows:

- The DSF was able to provide adequate fresh air at a differential heating temperature of about $12{ }^{\circ} \mathrm{C}$ in January 2013.

- The highest outlet temperature in the DSF reached about $41{ }^{\circ} \mathrm{C}$ as against an ambient temperature of $36^{\circ} \mathrm{C}$.

- The maximum temperature increase obtained was $4.6{ }^{\circ} \mathrm{C}$ which could increase the cooling load in the building.

It is obvious that DSFs could enhance the energy efficiency of buildings if effective thermal management control strategies and systems are adopted to ensure appropriate ventilation supply rates in winter and to reduce excessive temperature gradients within the cavity during summer periods. More investigations covering different configurations of DSFs are however encouraged.

\section{Acknowledgments}

The authors wish to thank the Ningbo Science and Technology Bureau, China for supporting this research under the Key Laboratory of Integrated Thermal Energy Storage Technologies (ITEST) for buildings project.

\section{References}

[1] Zhou, J., Chen, Y., A review on applying ventilated double-skin facade to buildings in hot-summer and cold-winter zone in China. Renewable and Sustainable Energy Reviews 14 (2010) 1321-1328.

[2] Poirazis, H., Double Skin Façades-A Literature Review. A report of IEA SHC Task 34 ECBCS Annex 43, 2006

[3] Rovers, C., Final report on natural ventilation-as a means to reduce the energy consumption of the new UN HQS of Sustainability, 2012.

[4] Marques da Sliva, F., Gomes, M., Pinto, A., Pereira, A.I., Moret Rodrigues, A., Double-skin façade thermal monitoring, in: Proceedings of the Healthy Buildings, vol. III, Lisbon, Portugal, 2006, pp. 111-116. 
[5] Perino, M., Corgnati, S.P., Serra, V., Experimental assessment of the performance of an active transparent fac, ade during actual operating conditions, Solar Energy 81 (2007) 993-1013.

[6] Faggembauu, D., Costa, M., Soria, M., Oliva, A., Numerical analysis of the thermal behaviour of ventilated facades in Mediterranean climates. Part II. Application and analysis of results, Solar Energy 75 (2003) 229-239.

[7] Tanimoto, J., Kimura, K., Simulation study on an airflow window system with an integrated roll screen, Energy and Buildings 26 (1997) 317-325.

[8] Gratia, E., De Herde, A., Natural ventilation in a double-skin façade, Energy and Buildings 36 (2004) 137-146.

[9] Gratia, E., De Herde, A., Optimal operation of a south double-skin façade, Energy and Buildings 36 (2004) 41-60.

[10] Kalyanova, G., Heiselberg, P., IEA ECBCS Annex43/SHC Task 34, Validation of Building Energy Simulation Tools, ISSN 1901-726X, DCE Technical Report No. 027, June 2009.

[11] Park, C-S., Occupant responsive optimal control of smart facade systems. College of Architecture, Georgia Institute of Technology. 2003

[12] Jiru, T.E., Haghighat, F., Modelling ventilated double skin facade: A zonal approach. Energy and Buildings, 40(2008), 1567-1576.

[13] Hanby, V.I., Cook, M.J., Infield, D.J., Ji, Y., Loveday, D.L., Mei, L., Nodal network and CFD simulation of airflow and heat transfer in double skin facades with blinds. Building Services Engineering Research and Technology, 29 (2008), 45-59.

[14] Hoseggen, R., Wachenfeldt, B.J., Hanssen, S.O., Building simulation as an assisting tool in decision making. Case study: With or without a double-skin facade? Energy and Buildings, 40 (2008), 821-827.

[15] Inc., A., ed. Fluent 6.3 User Guide. 2007. Chapter 13.2.1

[16] Inc., A., ed. Fluent 6.3 User Guide. 2007. Chapter 9.2

[17] Inc., A., ed. Fluent 6.3 User Guide. 2007. Chapter 12.4.3

[18] Inc., A., ed. Fluent 6.3 User Guide. 2007. Chapter 12.2.4

[19] Inc., A., ed. Fluent 6.3 User Guide. 2007. Chapter 12.2.7

[20] Kalyanova, J., Heiselberg, P., IEA ECBCS Annex43/SHC Task 34, Validation of Building Energy Simulation Tools, ISSN 1901-726X, DCE Technical Report No. 027, June 2009.

[21] Kim, Y-M., Lee, J-H., Ki m, S-M., Effects of double skin envelopes on natural ventilation and heating loads in office buildings, Energy Buildings 43 (2011), 21182126.

[22] Appelfeld, D., Svendsen, S., Experimental analysis of energy performance of a ventilated window for heat recovery under controlled conditions, Energy \& Buildings, Volume 43, issue 11 (November, 2011), p. 3200-3207.

[23] Zöllner, A., Winter, E.R.F., Viskanta, R., Experimental studies of combined heat transfer in turbulent mixed convection fluid flows in double-skin-facades. International Journal of Heat and Mass Transfer 45 (2002), 4401-4408. 


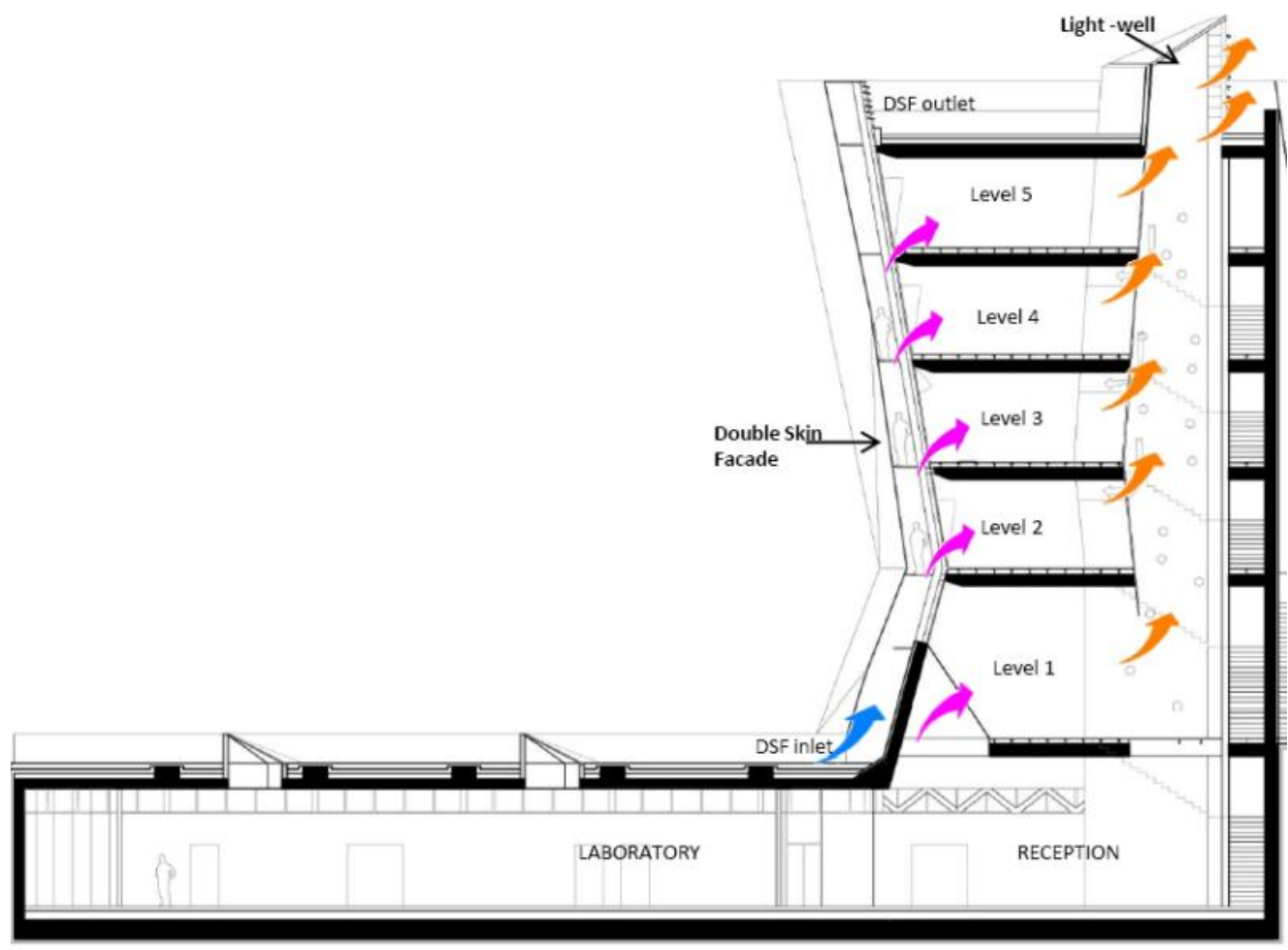

(a): Winter mode

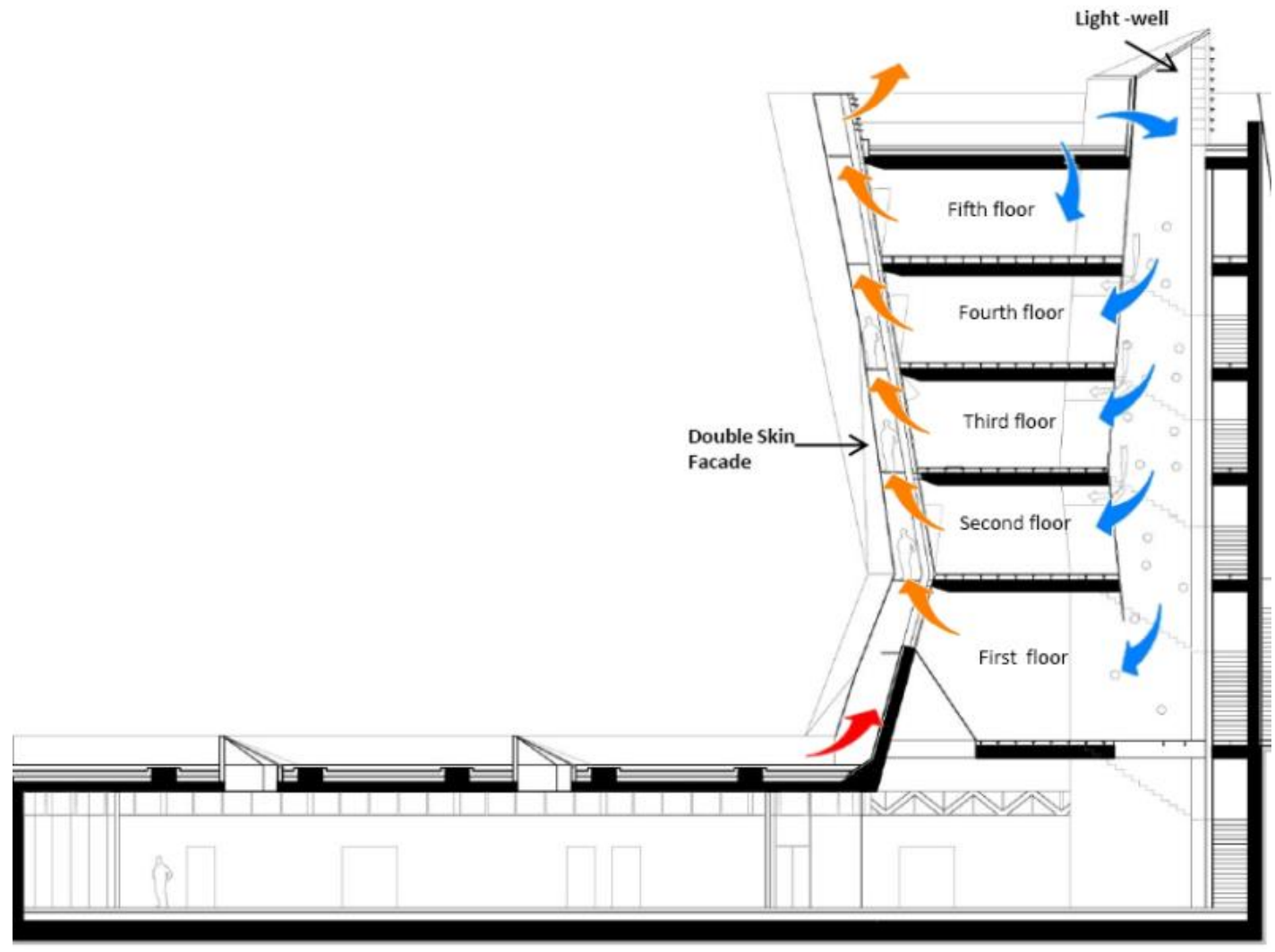

(b): Summer mode

Figure 1: Ventilation strategy of DSF 


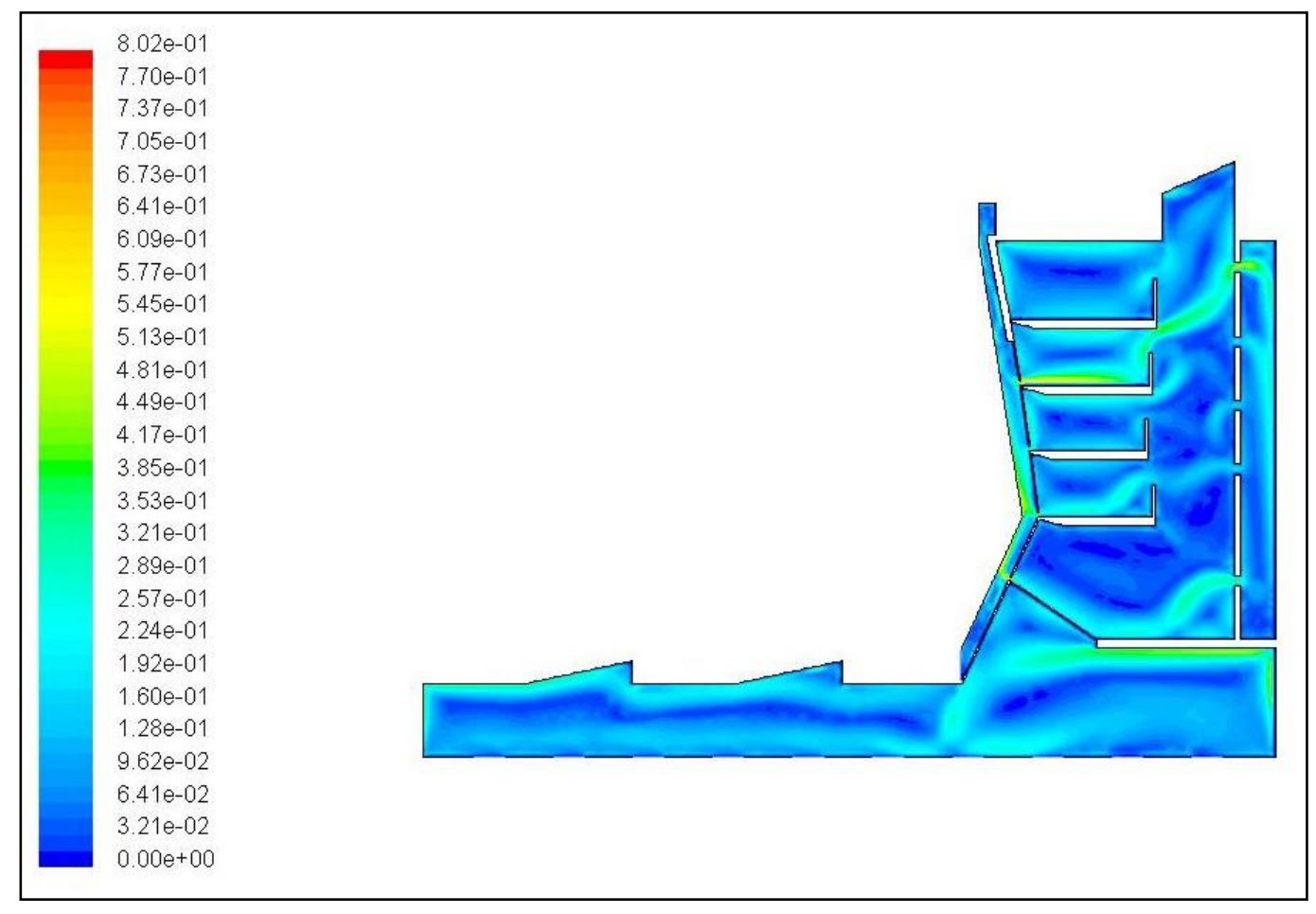

Figure 2: $\quad$ Velocity magnitude contours of winter model $(\mathrm{m} / \mathrm{s})$ 


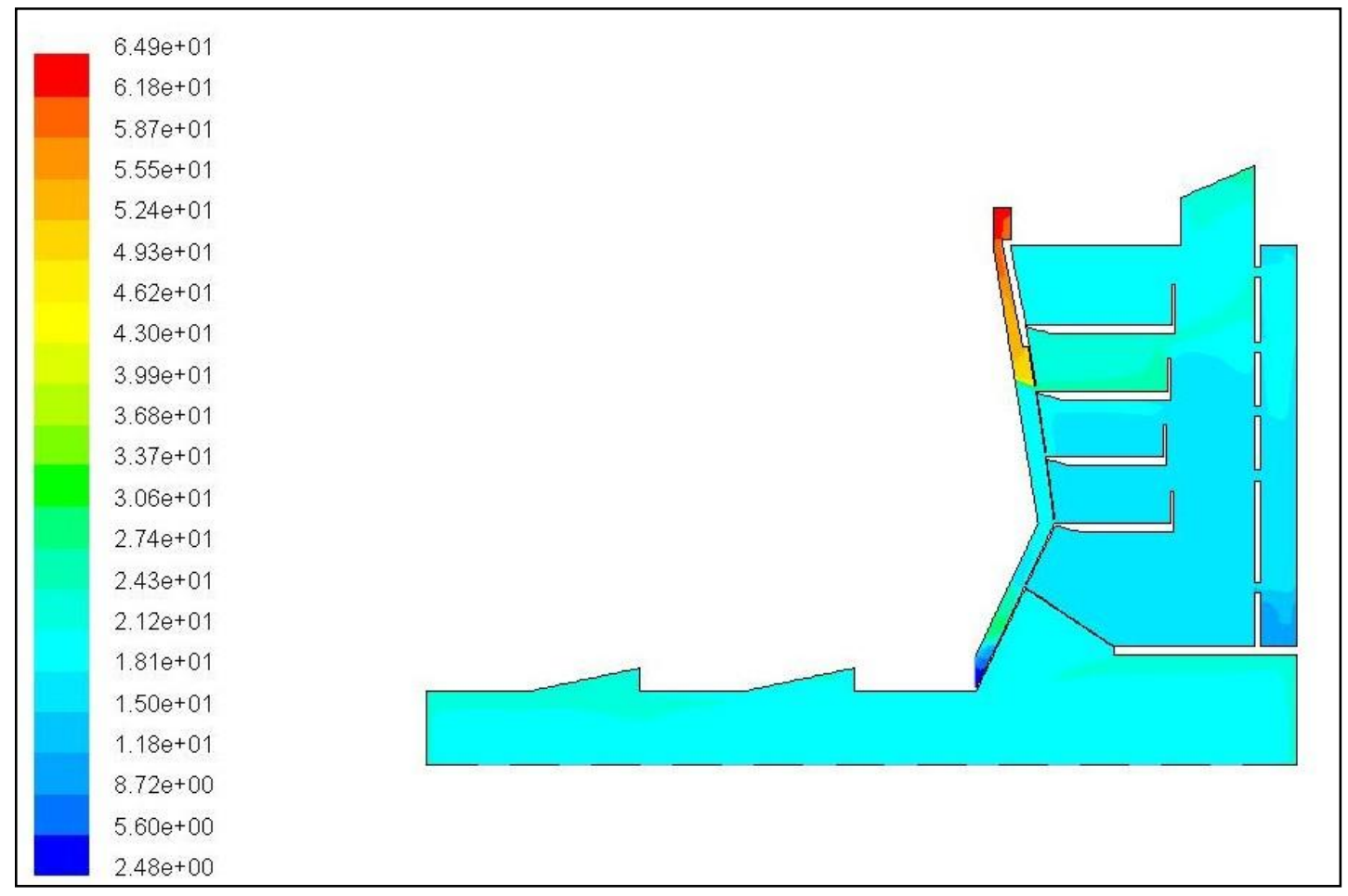

Figure 3: $\quad$ Temperature contours for winter model $\left({ }^{\circ} \mathrm{C}\right)$. 


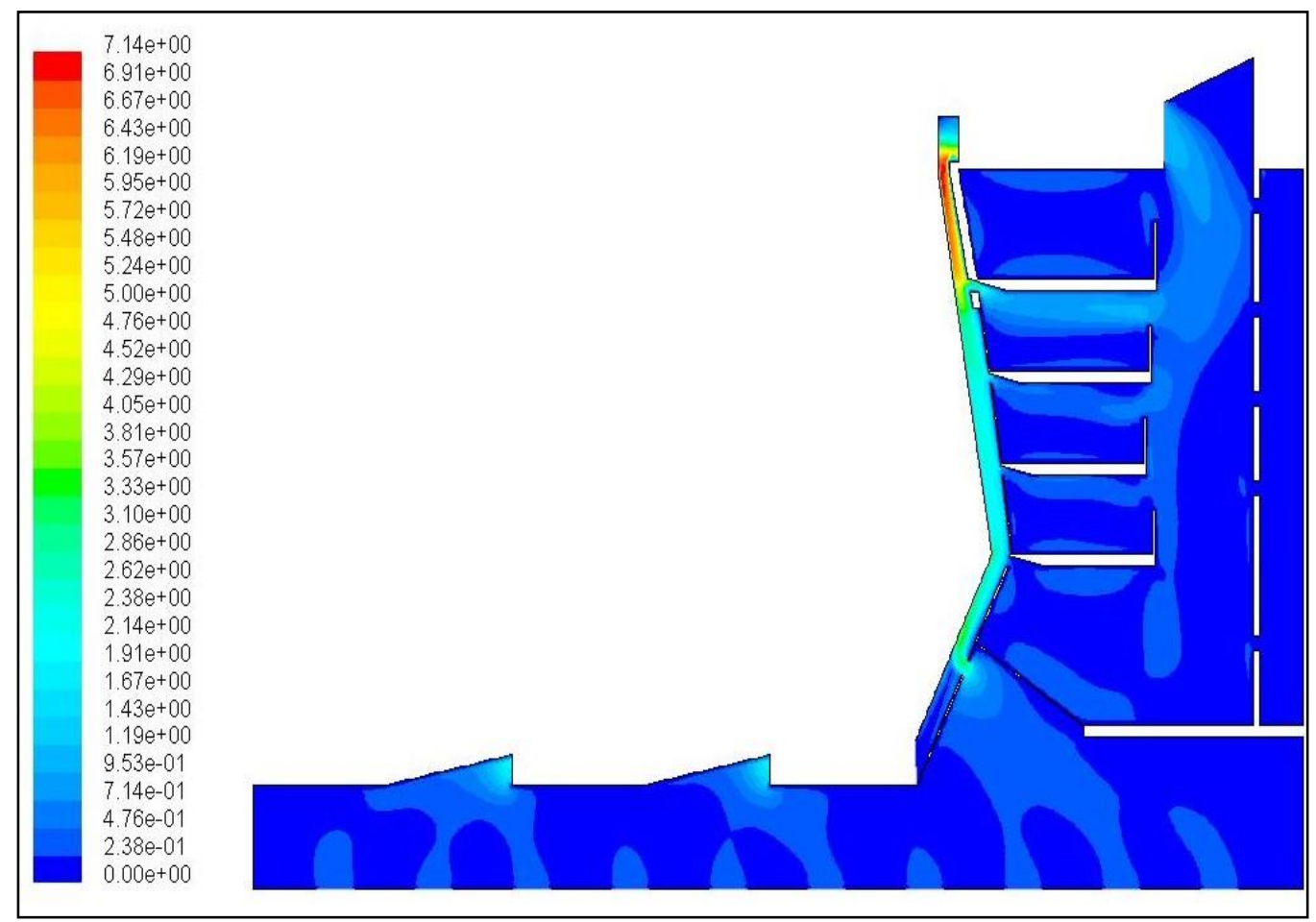

Figure 4: Velocity magnitude contours for summer model $(\mathrm{m} / \mathrm{s})$. 


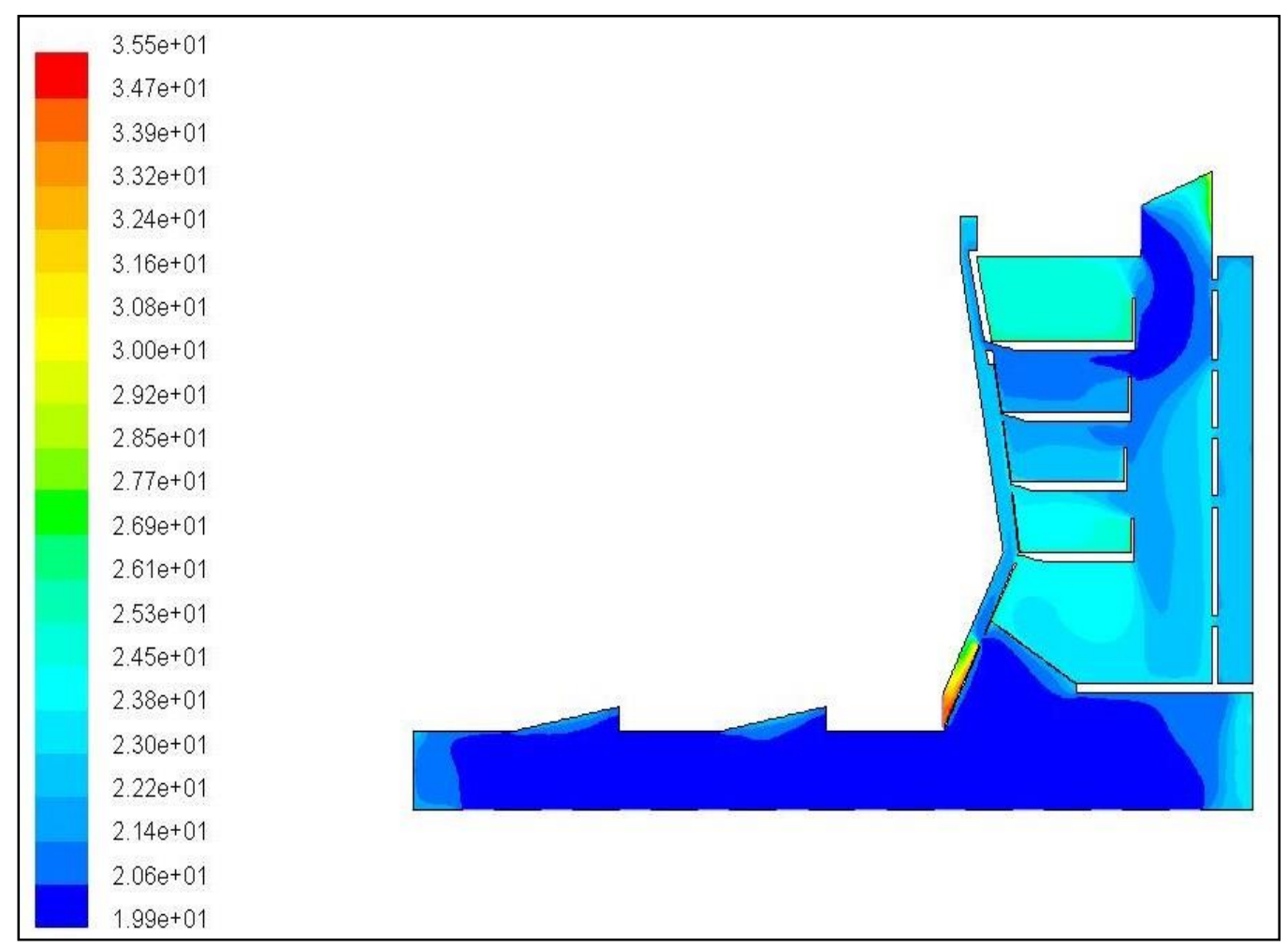

Figure 5: Air Temperature contours of summer model $\left({ }^{\circ} \mathrm{C}\right)$. 


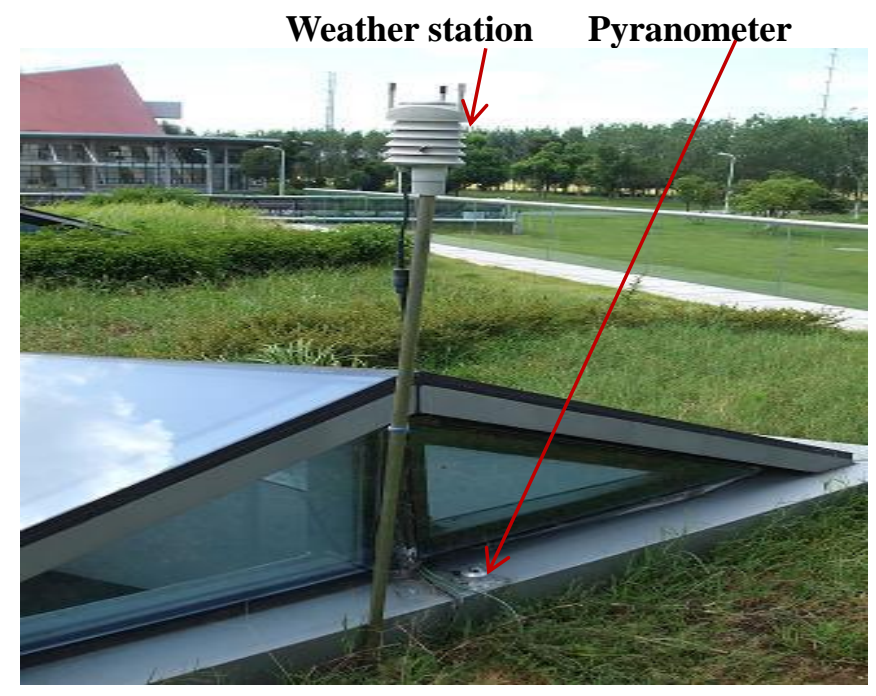

Figure 6: Meteorological and Solar radiation installation 


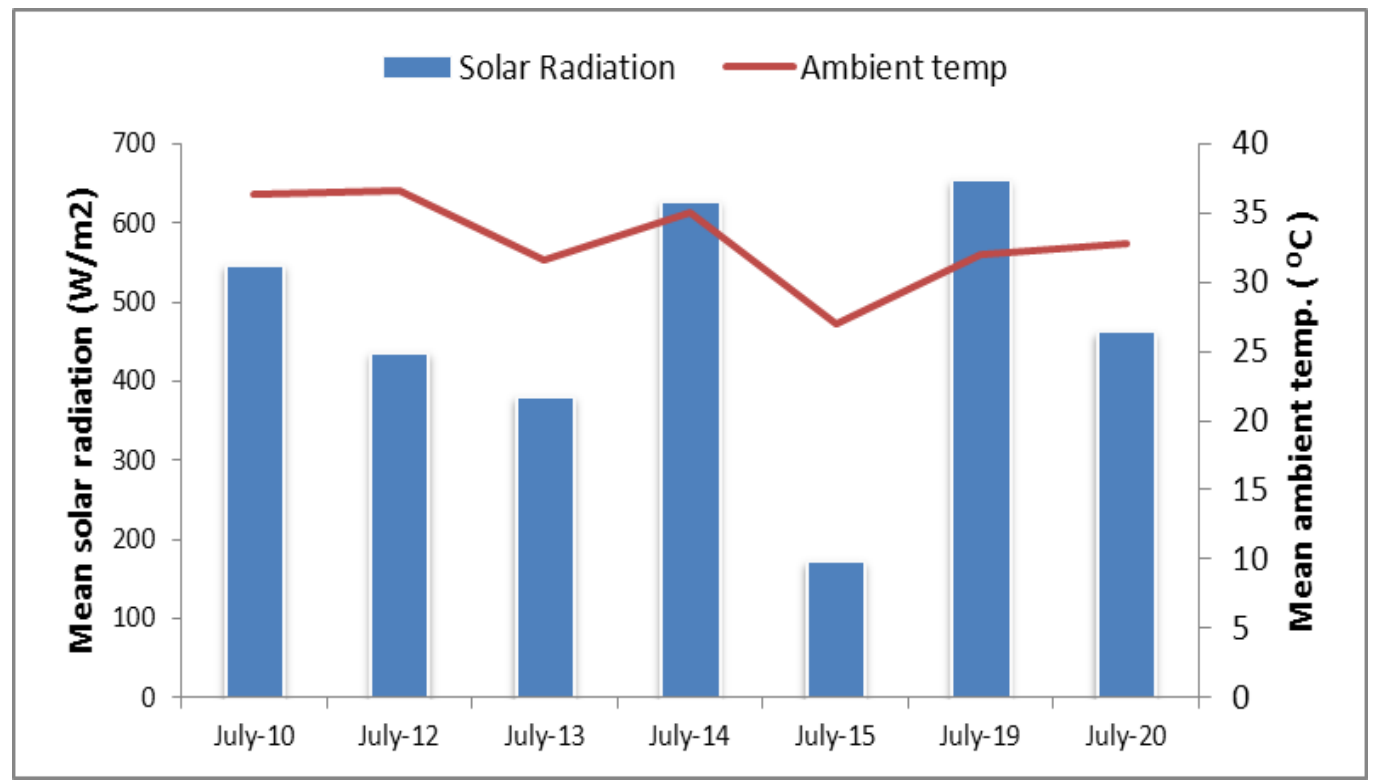

Figure 7: Solar radiation and ambient temperature for monitored days- July 2012. 


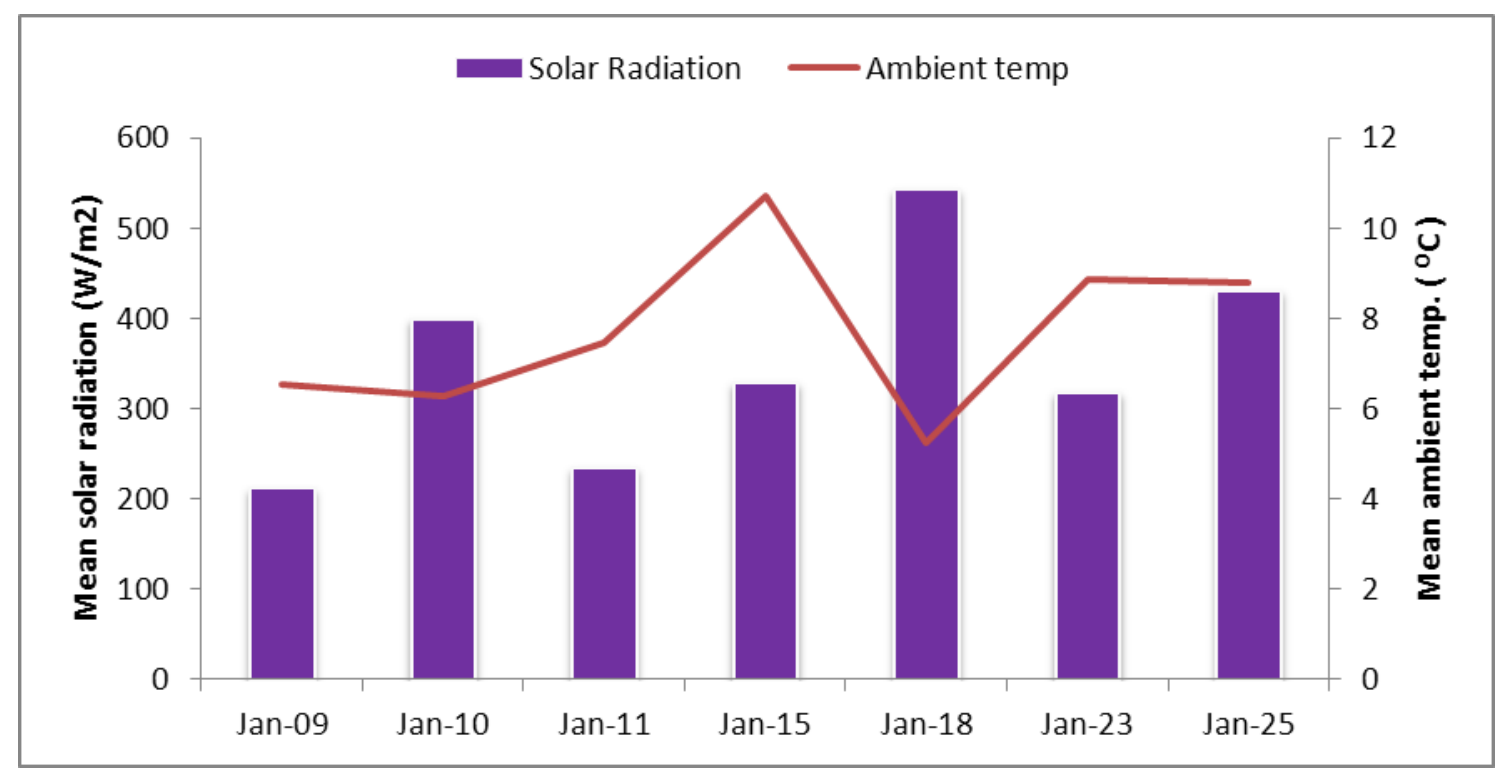

Figure 8: Solar radiation and ambient temperature for monitored days- Jan. 2013. 


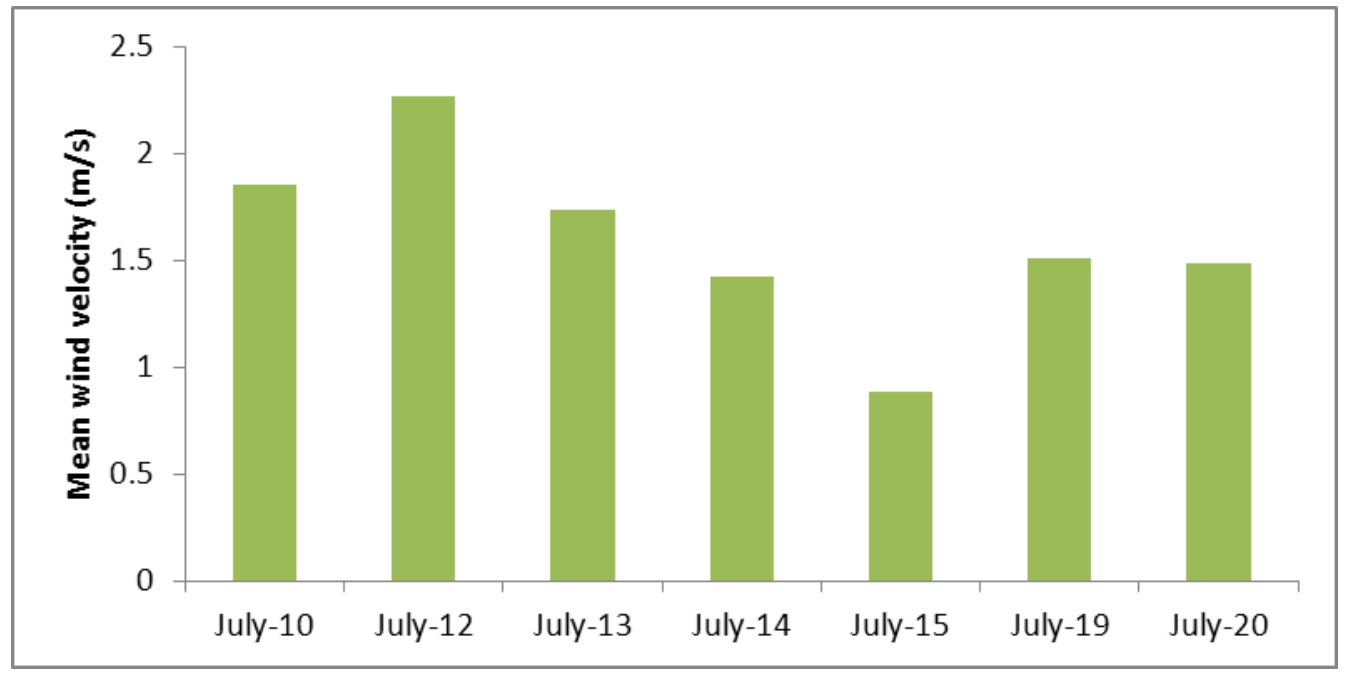

Figure 9: Wind velocity profiles for monitored days- July 2012 


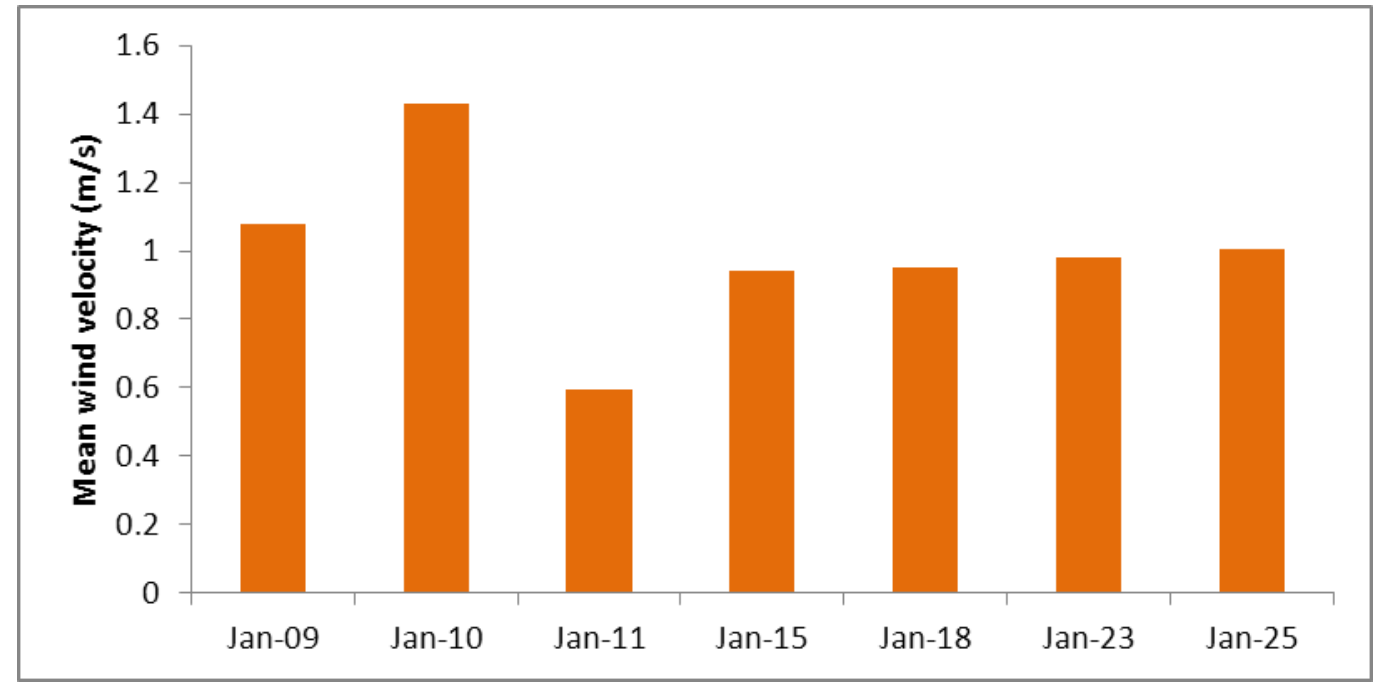

Figure 10: Wind velocity profiles for monitored days- Jan. 2013. 


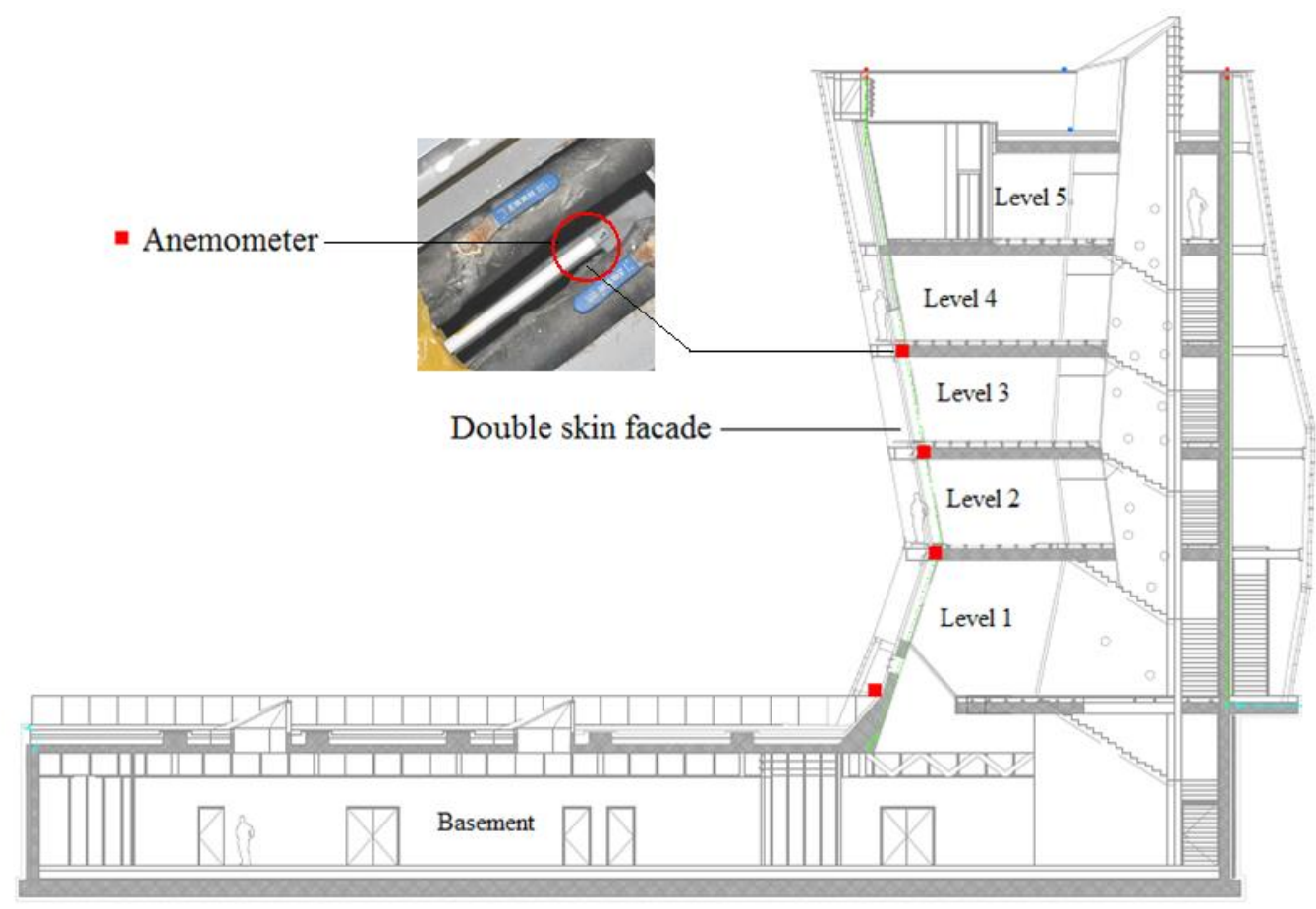

Figure 11: Air velocity measuring points-Winter 


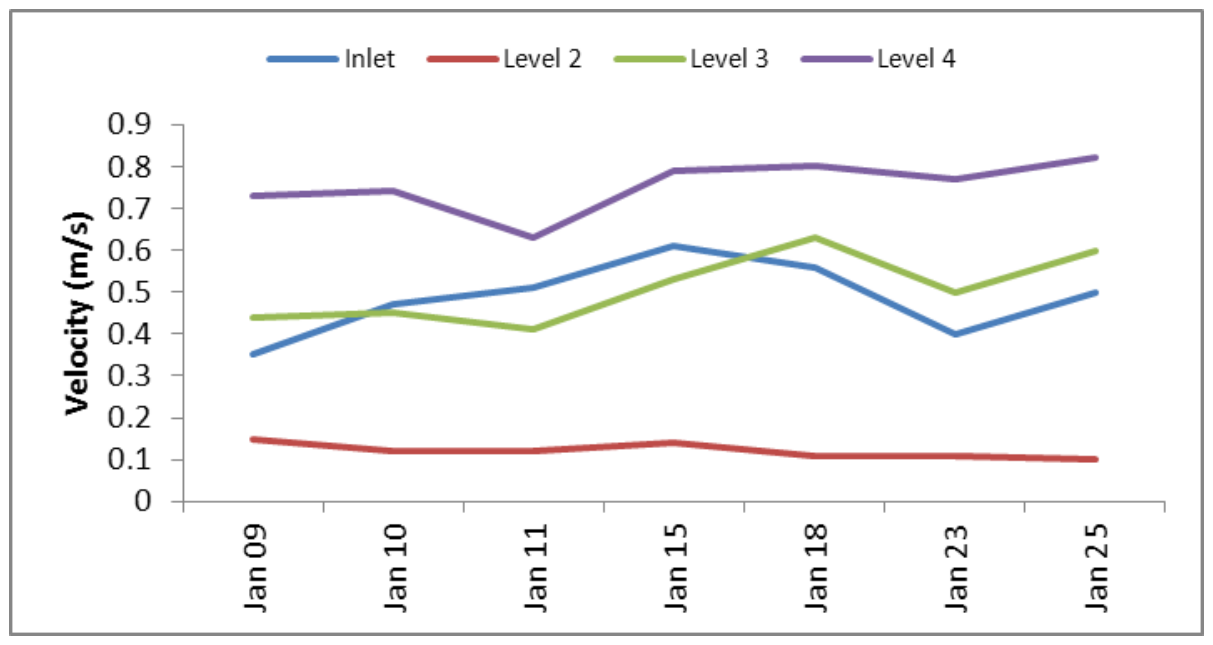

Figure 12: Mean air velocity profiles selected days in January 2013. 


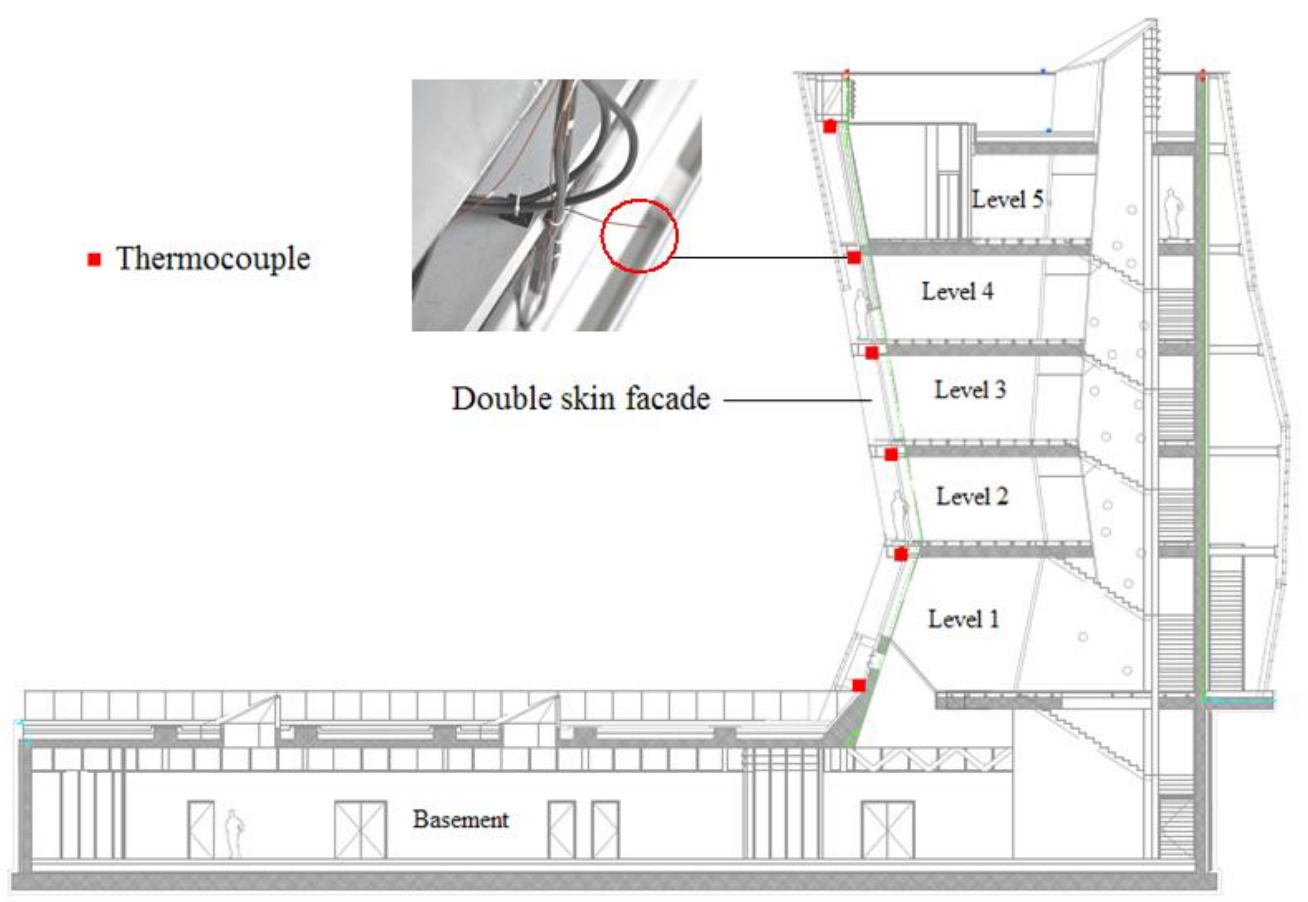

Figure 13: Air temperature measuring points for winter and summer 


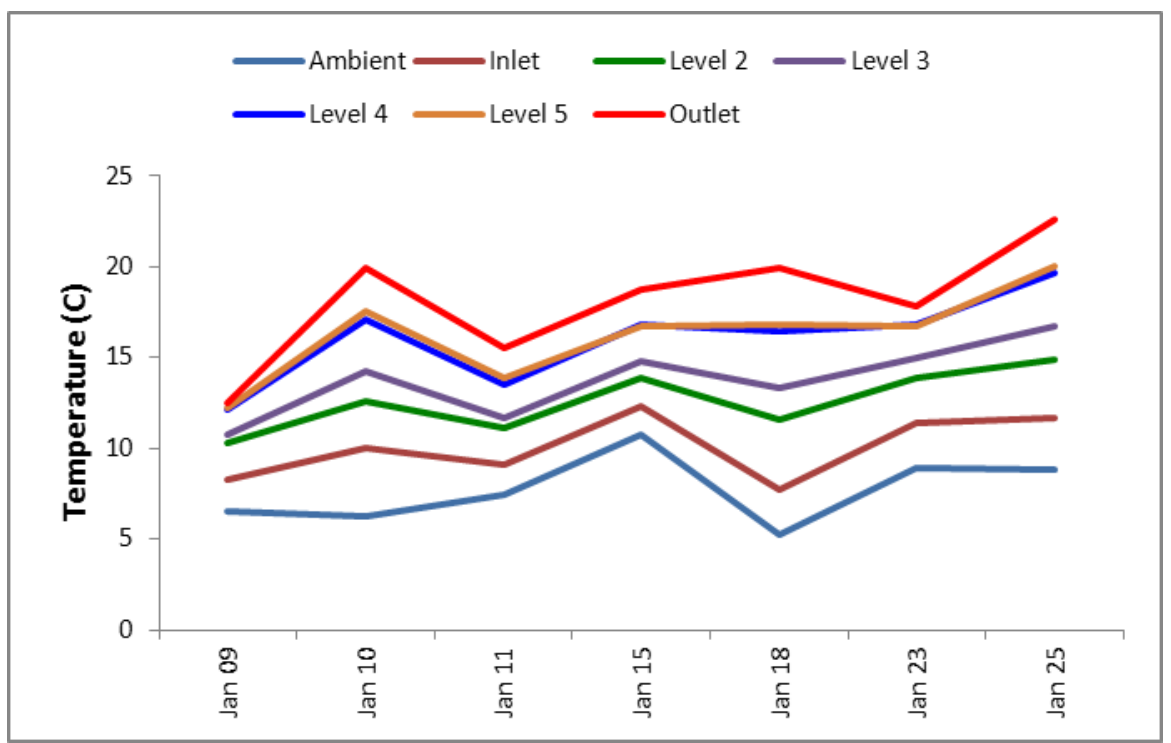

Figure 14: Mean air temperature profiles for selected days in January 2013. 


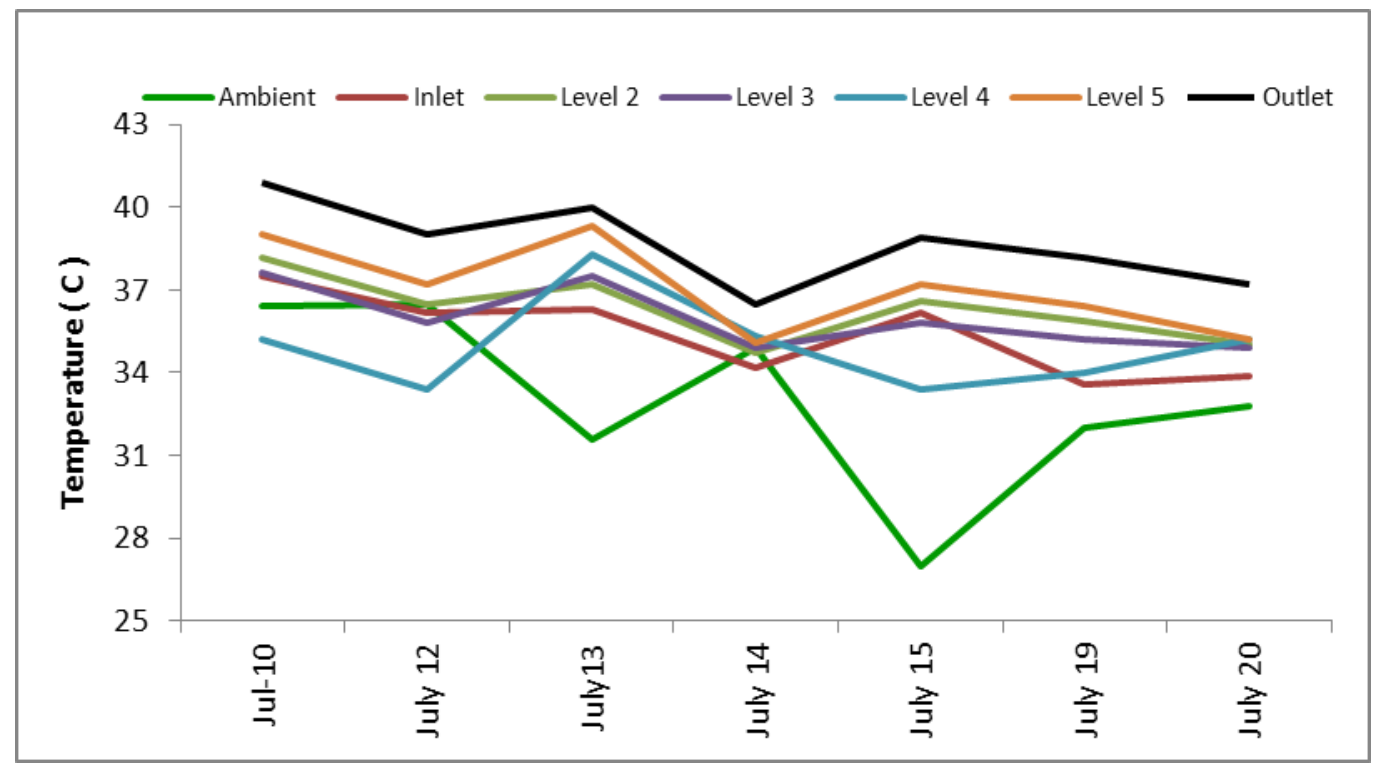

Figure 15: Mean air temperature profiles for selected days in July 2012 


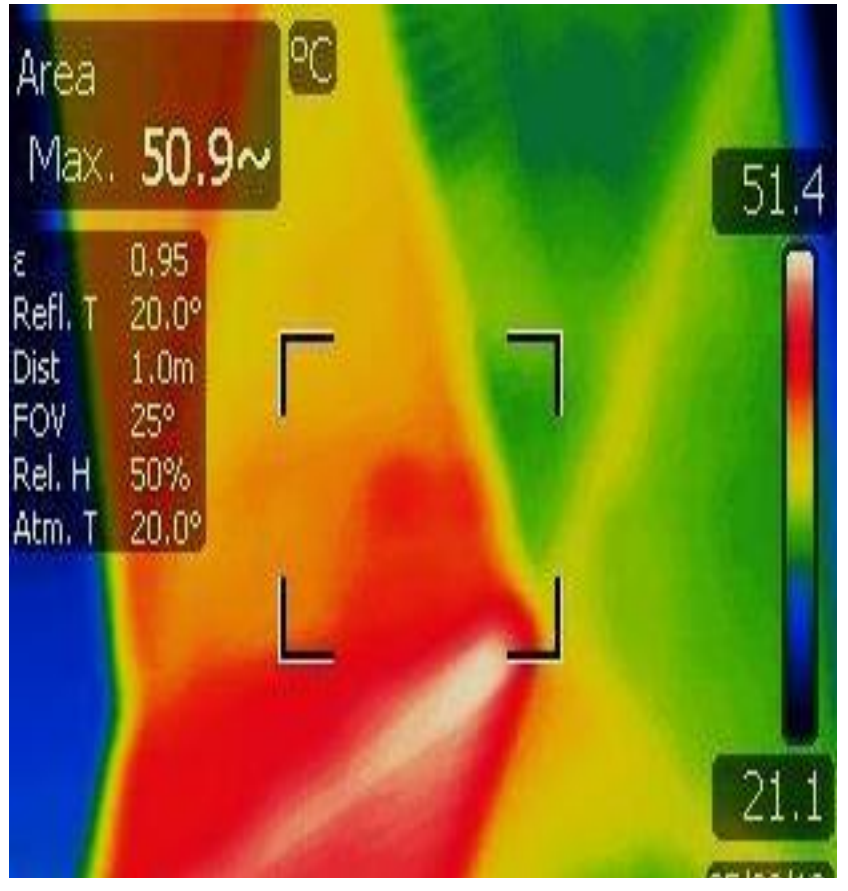

Figure 16: Thermographic image of the DSF in July 2012 